\title{
PERTANGGUNGJAWABAN PIDANA KORPORASI BERDASARKAN CORPORATE CULTURE MODEL DAN IMPLIKASINYA BAGI KESEJAHTERAAN MASYARAKAT
}

\author{
(Corporate Criminal Liability Based on Corporate Culture Model \\ and Implications for Welfare of Community) \\ Budi Suhariyanto \\ Pusat Penelitian dan Pengembangan Hukum dan Peradilan MA-RI \\ Jl. Jend. Ahmad Yani Kav.58 Jakarta Pusat \\ Email: penelitihukumma@gmail.com
}

Naskah diterima: 11 September 2017; revisi: 7 November 2017; disetujui: 8 November 2017

\begin{abstract}
Abstrak
Iklim usaha yang sehat adalah kunci stabilitas perekonomian dan kesejahteraan suatu bangsa. Perilaku yang curang dalam persaingan usaha dengan cara menyuap atau korupsi, dapat dilakukan oleh dan atas nama serta untuk keuntungan korporasi. Dalam rangka efektivitas pemberantasan tindak pidana korporasi maka Perma Nomor 13 Tahun 2016 memberlakukan corporate culture model dimana korporasi dapat dipersalahkan jika tidak melakukan pencegahan atau memiliki kondisi budaya kerja yang tak menghindarkan terjadinya tindak pidana pengurusnya. Patut dipertanyakan bagaimanakah eksistensi pertanggungjawaban pidana korporasi pelaku dalam peraturan perundang-undangan dan bagaimanakah pertanggungjawaban pidana korporasi berdasarkan corporate culture model dan implikasinya bagi kesejahteraan masyarakat? Untuk menjawabnya maka digunakan metode penelitian hukum normatif. Disimpulkan bahwa ketidakjelasan perundang-undangan mengatur pertanggungjawaban pidana korporasi pelaku korupsi menjadi kedala penegakan hukum. Penerbitan Perma Nomor 13 Tahun 2016 yang mengatur perluasan pertanggungjawaban korporasi merupakan upaya optimalisasi pemberantasan tindak pidana korupsi. Namun pertanggungjawaban pidana berdasarkan corporate culture model harus diterapkan secara hati-hati karena akan berpengaruh bagi dunia usaha serta stabilitas kesejahteraan masyarakat.
\end{abstract}

Kata Kunci: pertanggungjawaban korporasi, corporate culture model, kesejahteraan masyarakat

\begin{abstract}
A healthy business climate is the key to economic stability and for the wellbeing of a nation. Unfair practices in business competition by means of bribery and corruption, can be conducted by, on behalf of, and for the benefit of the corporation. For the effectiveness of the eradication of corporate crimes, Supreme Court Regulation (Perma) No. 13 of 2016 implements a corporate culture model in which the corporation can be blamed if it is not preventing or having a working culture/ condition that does not prevent its criminal offense. It is questionable how the existence of corporate criminal liability in legislation is and how is corporate criminal liability under corporate culture model and its implications for the welfare of society? To answer it, normative legal research method was utilized. It is concluded that the lack of clarity of legislation regulating the corporate criminal liability of corruption to be the constraint of law enforcement. The issuance of Perma No. 13 of 2016 regulating the extension of corporate liability is an effort to optimize the eradication of corruption effort. However, criminal liability under corporate culture model must carefully be applied as it will affect the business world and the stability of the people's welfare.
\end{abstract}

Keywords: corporate responsibility, corporate culture model, welfare society 


\section{A. Pendahuluan}

Korporasi sebagai suatu entitas atau subjek hukum yang keberadaannya memberikan kontribusi yang besar dalam meningkatkan pertumbuhan ekonomi dan pembangunan nasional, namun dalam kenyataannya korporasi ada kalanya juga melakukan pelbagai tindak pidana (corporate crime) yang membawa dampak kerugian terhadap negara dan masyarakat. ${ }^{1}$ Dalam menghadapi persaingan, korporasi dihadapkan pada penemuan teknologi baru, teknik pemasaran, dan usahausaha memperluas atau menguasai pasar. Keadaan ini dapat menghasilkan tindakan korporasi untuk memata-matai saingannya, meniru, memalsukan, mencuri, menyuap, dan mengadakan persekongkolan mengenai harga atau daerah pemasaran. Singkatnya, karena dorongan persaingan, korporasi dapat dan seringkali melakukan suatu tindak pidana dalam rangka mencapai tujuan. ${ }^{2}$

Menurut kualifikasinya, kejahatan korporasi tergolong sebagai white collar crime yang menggunakan modus operandi yang canggih dan dapat juga berdimensi transnasional dimana dilakukan lintas Negara dan teritorial. Gabungan dari kedua kualifikasi tersebut menghasilkan ruang lingkup kejahatan yang luas dan dampak kerugian yang sangat besar. Dikatakan demikian karena korban yang ditimbulkan akibat kejahatan yang dilakukan korporasi meliputi masyarakat pada umumnya, konsumen pengguna produk yang dihasilkan, korporasi yang bertindak selaku kompetitor, dan para karyawan atau buruh yang tidak terlindungi. Bahkan Negara pun dapat menjadi korban kejahatan korporasi dimana tindak pidana korporasi menimbulkan kerugian keuangan Negara atau perekonomian Negara. ${ }^{3}$ Untuk mengamankan kebijakan ekonominya, pemerintah sudah seharusnya memperluas peraturan yang mengatur kegiatan bisnis, baik melalui peraturan baru maupun penegakan yang lebih keras ${ }^{4}$ khususnya yang terkait dengan pertanggungjawaban hukum korporasi pelaku tindak pidana.

Permasalahan pertanggungjawaban korporasi pelaku tindak pidana adalah suatu hal yang tidak sederhana, mengingat korporasi adalah badan hukum. Permasalahan ini berpangkal pada adanya asas tiada pidana tanpa kesalahan. Kesalahan adalah mens rea atau sikap kalbu yang secara alamiah hanya ada pada orang alamiah. Mens rea adalah unsur yang sulit dibuktikan dari korporasi yang dianggap melakukan tindak pidana mengingat korporasi hanya bisa melakukan tindakan melalui organ direksi. Korporasi bisa dianggap melakukan tindak pidana berdasarkan perbuatan yang dilakukan oleh orang yang mengontrol pengurusan korporasi. ${ }^{5}$ Konstruksi yuridis yang dipakai untuk mengatakan bahwa korporasi telah melakukan tindak pidana adalah apabila tindak pidana itu dilakukan oleh pengurus atau pegawai korporasi yang masih dalam ruang

1 Konsideran huruf a Peraturan Mahkamah Agung Nomor 13 Tahun 2016 tentang Tata Cara Penanganan Perkara Tindak Pidana Oleh Korporasi

I. S. Susanto, Kejahatan Korporasi, , (Semarang: BP Universitas Diponegoro, 1995), hlm.30.

3 Kristian, Hukum Pidana Korporasi: Kebijakan Integral (Integral Policy) Formulasi Pertanggungjawaban Pidana Korporasi di Indonesia, (Bandung: Nuansa Aulia, 2014), hlm.33.

Ibid, hlm.30.

5 Hasbullah F. Sjawie, Direksi Perseroan Terbatas serta Pertanggungjawaban Pidana Korporasi, (Bandung: Citra Aditya Bhakti, 2013), hlm.262-263. 
lingkup kewenangannya dan untuk kepentingan korporasi. $^{6}$

Sekitar 100 (seratus) undang-undang yang mengatur pertanggungjawaban korporasi seperti Undang-Undang tentang Pertambangan, Mineral dan Batubara, UndangUndang tentang Kehutanan, Undang-Undang tentang Lingkungan Hidup, Undang-Undang tentang Tata Ruang, Undang-Undang tentang Pemberantasan Tindak Pidana Korupsi, UndangUndang tentang Tindak Pidana Pencucian Uang, Undang-Undang tentang Kepabeanan, dan lain sebagainya. Pengaturan yang sangat beragam menunjukkan politik hukum yang belum jelas misalnya dalam hal pemberian definisi, ruang lingkup tindak pidana, dan jenis sanksi pidana terhadap korporasi. Bahkan dalam hal perumusan pertanggungjawaban pidana korporasi dari berbagai perundangundangan tersebut berbeda. Ada sebagian yang membebankan kepada salah satu diantara pengurus atau korporasi saja dan ada pula yang menetapkan kedua-duanya dapat dituntutkan pertanggungjawaban pidananya secara bersamaan.

Ketidakjelasan pengaturan pertanggungjawaban pidana korporasi dalam perundangundangan di atas, menjadi salah satu kendala utama penegakan hukum dalam rangka pemberantasan tindak pidana korporasi. Misalnya dalam perkara tindak pidana korupsi, meskipun korporasi telah ditetapkan sebagai subjek hukum dan dapat dipertanggungjawabkan secara pidana sejak tahun 1999 (dimana Undang-Undang tentang Pemberantasan Tindak Pidana Korupsi mulai diberlakukan), tetapi sampai dengan tahun 2010 (sekitar 11 tahunan) belum pernah muncul perkara korupsi dimana korporasi dijadikan sebagai terdakwa dan dituntut serta dipidana. Baru dalam perkara PT. Giri Jaladhi Wana yang diajukan sebagai terdakwa oleh Kejaksaan dan dituntut ke pengadilan tindak pidana korupsi. ${ }^{7}$ Keberhasilan Jaksa dalam menuntutkan pertanggungjawaban pidana di peradilan ini didukung dengan perangkat kebijakan Penegak hukum berupa Surat Edaran Kejaksaan Agung RI Nomor B-36/A/Ft.1/06/2009 perihal Korporasi Sebagai Tersangka/Terdakwa Dalam Tindak Pidana Korupsi. Tanpa panduan dari surat edaran tersebut, perkara ini juga tidak akan muncul ke permukaan karena secara teknis hukum acara penanganan tindak pidana korporasi masih belum jelas. Kejaksaan Agung selanjutnya menyempurnakan Surat Edaran tersebut menjadi Peraturan Jaksa Agung Republik Indonesia Nomor:Per-028/A/JA/10/2014 tentang Pedoman Penanganan Perkara Pidana Dengan Subjek Hukum Korporasi.

Seiring sejalan dengan Kejaksaan Agung di atas, Mahkamah Agung menerbitkan Peraturan Mahkamah Agung Nomor 13 Tahun 2016 tentang Tata Cara Penanganan Perkara Tindak Pidana Oleh Korporasi. Perma Nomor 13 Tahun 2016memberikan definisi khusus terkait tindak pidana Korporasi yaitu tindak pidana yang dilakukan oleh orang berdasarkan hubungan kerja, atau berdasarkan hubungan lain, baik sendiri-sendiri maupun bersamasama yang bertindak untuk dan atas nama Korporasi di dalam maupun di luar Lingkungan

\footnotetext{
Mahrus Ali, Kejahatan Korporasi, (Yogyakarta: Arti Bumi Intaran, 2008). hlm.38.

7 Budi Suhariyanto, Progresivitas Putusan Pemidanaan Terhadap Korporasi Pelaku Tindak Pidana Korupsi, Jurnal De Jure Volume 16 Nomor 2 (Juni 2016), hlm.207.
} 
Korporasi. ${ }^{8}$ Perma Nomor 13 Tahun 2016 juga menentukan bahwa dalam menjatuhkan pidana terhadap Korporasi, Hakim dapat menilai kesalahan Korporasi antara lain: (a). Korporasi dapat memperoleh keuntungan atau manfaat dari tindak pidana tersebut atau tindak pidana tersebut dilakukan untuk kepentingan Korporasi; (b). Korporasi membiarkan terjadinya tindak pidana; atau (c). Korporasi tidak melakukan langkah-langkah yang diperlukan untuk melakukan pencegahan, mencegah dampak yang lebih besar dan memastikan kepatuhan terhadap ketentuan hukum yang berlaku guna menghindari terjadinya tindak pidana. ${ }^{9}$

Keberadaan Perma Nomor 13 Tahun 2016 telah menjadi angin segar bagi penegak hukum untuk semakin yakin dalam menindak korporasi yang melakukan tindak pidana. Terbukti tidak lama setelah diberlakukannya Perma ini, Komisi Pemberantasan Korupsi melakukan proses penyidikan dan menetapkan PT. Duta Graha Indah yang kini bernama PT Nusa Konstruksi Enjiniring menjadi Tersangka dalam kasus korupsi proyek pembangunan rumah sakit di Universitas Udayana. Berbeda halnya dengan perspektif Pengusaha yang khawatir mengenai penetapan pertanggungjawaban korporasi atas apa yang dilakukan oleh Pengurusnya, karena bisa saja Pengurusnya melakukan kejahatan yang tidak ada kaitannya dengan korporasi namun pertanggungjawaban atas kejahatan tersebut dibebankan kepada korporasi. Implikasi atas dipidananya korporasi tersebut adalah kerugian masyarakat, khususnya yang memiliki saham atas perusahaan publik yang dibebankan pertanggung jawaban pidana. Apalagi Perma Nomor 13 Tahun 2016 tidak memberikan perlindungan terhadap pemegang saham atas perusahaan publik yang dibebankan pertanggungjawaban pidana. ${ }^{10}$

Pengaturan dalam Perma Nomor 13 Tahun 2016 yang menentukan bahwa bahwa kesalahan dapat dibebankan disaat korporasi membiarkan terjadinya tindak pidana ini menjadi hal yang mengkhawatirkan bagi kalangan pengusaha. Jadi meskipun tidak secara nyata terbukti menguntungkan korporasi dan sepenuhnya menguntungkan pribadi Pengurus tetapi ternyata ditemukan bukti bahwa korporasi tidak mencegah tindak pidana Pengurus tersebut makajuga dapat dikenakan pertanggungjawaban pidananya kepada Korporasi. Termasuk juga dapat dipersalahkan bilamana Korporasi tidak melakukan langkah-langkah yang diperlukan untuk melakukan pencegahan, dampak yang lebih besar dan memastikan kepatuhan terhadap ketentuan hukum yang berlaku guna menghindari terjadinya tindak pidana. Dalam konteks ini Perma memperluas pembuktian kesalahan yaitu mengarah pada penerapan teori corporate culture model dimana korporasi dapat dipertanggungjawabkan pidana atas kesalahannya yang tidak melakukan pencegahan atau memiliki kondisi budaya kerja yang tak menghindarkan terjadinya tindak pidana.

\footnotetext{
Pasal 4 ayat (1) Peraturan Mahkamah Agung Nomor 13 Tahun 2016 tentang Tata Cara Penanganan Perkara Tindak Pidana OlehKorporasi

9 Pasal 4 ayat (2) Peraturan Mahkamah Agung Nomor 13 Tahun 2016 tentang Tata Cara Penanganan Perkara Tindak Pidana Oleh Korporasi

10 Hariyadi B. Sukamdani, Korporasi sebagai Subyek Hukum Pidana Pasca Perma No.13 Tahun 2016: Pandangan Dunia Usaha, (Makalah seminar dalam Rangka HUT IKAHI ke-64 tahun di Hotel Mercure Ancol Jakarta pada hari Selasa 21 Maret 2017), hlm.7.
} 
Perluasan pertanggungjawaban berdasarkan corporate culture model ini yang menyebabkan kekhawatiran para Pengusaha sesaat setelah diterbitkannnya Perma Nomor 13 Tahun 2016 karena dinilai berdampak pada stabilitas perekonomian Negara dan kesejahteraan masyarakat. Korelasi atas implikasi penerapan corporate culture model ini menarik untuk dikaji dengan mengetengahkan permasalahan diantaranya: (1). Bagaimanakah eksistensi pertanggungjawaban pidana korporasi pelaku korupsi dalam peraturan perundangundangan?; dan (2). Bagaimanakah relevansi pertanggungjawaban pidana korporasi berdasarkan corporate culture model dan implikasinya bagi stabilitas dunia usaha?

\section{B. Metode Penelitian}

Penelitian ini menggunakan metode normatif. Terdapat 3 (tiga) pendekatan untuk mengkaji ketiga permasalahan yang coba dibahas dengan metode penelitian normatif ini yaitu pendekatan perundang-undangan (statute approach), pendekatan kasus (case approach) serta pendekatan konseptual (conseptual approach). Pendekatan perundangundangan diperlukan dalam rangka menelusuri ratio legis dan dasar ontologis lahirnya peraturan perundang-undangan. ${ }^{11}$ Pendekatan kasus digunakan untuk menemukan the ratio decidendi atau reasoning, yaitu pertimbangan pengadilan untuk sampai pada suatu putusan ${ }^{12}$ dimana letak terobosan hukum yang bertujuan memberi akses keadilan. ${ }^{13}$ Pendekatan konseptual digunakan untuk memahami secara presisi dan akurat berbagai konsep yang digunakan oleh prinsip hukum dalam undangundang maupun doktrin para ahli hukum. ${ }^{14}$

Sumber data yang digunakan dalam penelitian adalah data sekunder yang terdiri atas bahan hukum primer berupa peraturan perundang-undangan, konvensi hukum internasional dan putusan pengadilan serta bahan hukum sekunder berupa literature dan hasil penelitian. Peraturan perundang-undangan yang digunakan antara lain Kitab UndangUndang Hukum Pidana (KUHP), UndangUndang Nomor 31 Tahun 1999 sebagaimana diubah oleh Undang-Undang Nomor 20 Tahun 2001 tentang Pemberantasan Tindak Pidana Korupsi, Rancangan Undang-Undang tentang Kitab Hukum Pidana (RUU KUHP), Peraturan Jaksa Agung Republik Indonesia Nomor:Per028/A/JA/10/2014 tentang Pedoman Penanganan Perkara Pidana Dengan Subjek Hukum Korporasi, Peraturan Mahkamah Agung Nomor 13 Tahun 2016 tentang Tata Cara Penanganan Perkara Tindak Pidana Oleh Korporasi, dan Surat Edaran Kejaksaan Agung RI Nomor B-036/A/Ft.1/06/2009 perihal Korporasi Sebagai Tersangka/Terdakwa Dalam Tindak Pidana Korupsi dan Konvensi internasional terkait pertanggungjawaban korporasi dalam tindak pidana korupsi yaitu United Nation Covention Against Corruption (UNCAC) 2003. Putusan pengadilan yang dikaji terkait dengan

Peter Mahmud Marzuki, Penelitian Hukum (Jakarta: Kencana, 2014), hlm. 93-94.

Ibid, hlm.64

3 Sulistyowati Irianto dan Lim Sing Meij, Praktik Penegakan Hukum: Arena Penelitian Sosiolegal Yang Kaya. Dalam Sulistyowati Irianto dan Shidarta. Metode Penelitian Hukum (Konstelasi dan Refleksi) (Jakarta: Yayasan Pustaka Obor Indonesia. 2011), hlm. 191.

14 Peter Mahmud Marzuki, Loc Cit, hlm.178 
putusan pemidanaan korporasi pelaku tindak pidana korupsi diantaranya yaitu Putusan Pengadilan Negeri Banjarmasin Nomor : 812/ Pid .Sus /2010 /PN.Bjm, Putusan Pengadilan Tinggi Banjarmasin Nomor 04/PID.SUS/2011/ PT.BJM, Putusan Pengadilan Negeri Jakarta Pusat Nomor 234/PID.B/2011/PN.JKT.PST, Putusan Pengadilan Tinggi Jakarta Nomor 241/ PID/2012/PT.DKI, Putusan Mahkamah Agung Nomor 2239 K/PID.SUS/2012.

Adapun literature yang digunakan dalam kajian agar terhindar dari kekeliruan pandangan adalah yang berkaitan dengan filsafat pemidanaan dan teori pertanggungjawaban pidana korporasi. Bahan-bahan hukum dan literatur tersebut dikumpulkan melalui metode sistematis dan dicatat dalam kartu antara lain permasalahannya, asas-asas, argumentasi, implementasi yang ditempuh, alternatif pemecahannya dan lain sebagainya. Data yang telah dikumpulkan kemudian dideskripsikan dan diinterpretasikan sesuai pokok permasalahan selanjutnya disistematisasi, dieksplanasi, dan diberikan argumentasi. Metode analisis yang diterapkan untuk mendapatkan kesimpulan atas permasalahan yang dibahas adalah melalui analisis yuridis kualitatif.

\section{Pembahasan}

\section{Eksistensi Pertanggungjawaban Pidana Korporasi Pelaku Korupsi dalam Perundang-Undangan}

Pada awalnya, pembuat undang-undang berpandangan bahwa hanya manusia (orang per orang atau individu) saja yang dapat menjadi subjek hukum suatu tindak pidana. Hal ini dapat dilihat dari sejarah perumusan ketentuan Pasal 59 KUHP, terutama dari cara bagaimana delik dirumuskan dengana danya frasa "hij die" yang berarti "barang siapa". Dalam perkembangannya pembuat undang-undang ketika merumuskan delik turut memperhitungkan kenyataan bahwa manusia juga terkadang melakukan tindakan di dalam atau melalui organisasi dalam hukum keperdataan ataupun di luar hal tersebut, sehingga muncul pengaturan terhadap badan hukum atau korporasi sebagai subjek hukum dalam hukum pidana. ${ }^{15}$ Namun demikian hingga saat ini KUHP masih belum menempatkan korporasi sebagai subjek hukum pidana. Akan tetapi berbagai peraturan perundang-undangan yang ada di luar KUHP telah mengakui dan menempatkan korporasi sebagai subjek hukum pidana di samping manusia. ${ }^{16}$ Sayangnya dari berbagai perundang-undangan yang mengatur tentang korporasi tersebut ternyata memiliki perbedaan dalam hal memberikan definisi, ruang lingkup, jenis sanksi, hukum acara, dan bentuk pertanggungjawaban pidana terhadap korporasi sebagai subjek hukum tersebut berbeda-beda dan tidak harmonis.

Khusus untuk perkara tindak pidana korupsi, diaturnya korporasi sebagai subjek hukum pidana dalam Undang-Undang Nomor 31 Tahun 1999 jo. Undang-Undang Nomor 20 Tahun 2001 tentang Pemberantasan Tindak Pidana Korupsi merupakan kebijakan hukum pidana yang tepat. Jika sebelumnya subyek hukum tindak pidana korupsi hanya terkait dengan orang yang mana lebih khusus lagi terkait dengan pegawai negeri (vide Pasal 2 Undang-Undang Nomor 3 Tahun 1971 tentang Pemberantasan Tindak Pidana

Eddy O.S. Hiariej, Prinsip-Prinsip Hukum Pidana, (Yogyakarta: Cahaya Atma Pustaka, 2014), HIm.155.

16 Hasbullah F. Sjawie, Op Cit, Hlm.312. 
Korupsi), saat ini pengertian orang tersebut tidak semata diartikan sebagai manusia tetapi juga meliputi korporasi (vide Pasal 1 angka 3 Undang-Undang Nomor 31 tahun 1999 Jo. Undang-Undang Nomor 20 Tahun 2001 tentang Pemberantasan Tindak Pidana Korupsi.

Mekanisme pertanggungjawaban dan sistem pemidanaannya diatur secara rinci yaitu dalam hal tindak pidana korupsi dilakukan oleh atau atas nama suatu korporasi, maka tuntutan dan penjatuhan pidana dapat dilakukan terhadap korporasi dan atau pengurusnya (vide Pasal 20 ayat (1) Undang-Undang tentang Pemberantasan Korupsi). Artinya secara komulatif-alternatif dapat dituntut dan diputus pemidanaannya bilamana dilakukan oleh atau atas nama suatu korporasi sehingga dapat dilakukan terhadap "korporasi dan pengurus" atau terhadap "korporasi" saja atau "pengurus" saja. Selanjutnya untuk mengidentifikasi bahwa tindak pidana korupsi dilakukan oleh korporasi adalah apabila tindak pidana tersebut dilakukan oleh orang-orang baik berdasarkan hubungan kerja maupun berdasarkan hubungan lain, bertindak dalam lingkungan korporasi tersebut baik sendiri maupun bersama-sama (vide Pasal 20 ayat (2) UU Undang-Undang tentang Pemberantasan Korupsi).

Secara teknis dalam hal tuntutan pidana dilakukan terhadap suatu korporasi, maka korporasi tersebut diwakili oleh pengurus. Pengurus yang mewakili korporasi dapatdiwakili oleh orang lain (vide Pasal 20 ayat (3) jo Pasal 20 ayat (4) Undang-Undang tentang Pemberantasan Korupsi). Meskipun demikian Hakim dapat memerintahkan agar pengurus korporasi tersebut menghadap sendiri pada pemeriksaan disidang pengadilan dan dapat pula hakim memerintahkan agar pengurus yang dimaksud dibawa ke sidang pengadilan (vide Pasal 20 ayat (5) Undang-Undang tentang Pemberantasan Korupsi).Dalam hal tuntutan pidana dilakukan terhadap korporasi, maka panggilan untuk menghadap dan penyerahan surat panggilan tersebut disampaikan kepada pengurus di tempat tinggal pengurus atau di tempat pengurus berkantor. Pidana pokok yang dapat dijatuhkan terhadap korporasi hanya pidana denda, dengan ketentuan maksimum pidana ditambah sepertiga (vide Pasal 20 ayat (6) dan ayat (7) Undang-Undang tentang Pemberantasan Korupsi).

Jika diteliti dengan seksama, formulasi aturan pemidanaan (pertanggungjawaban pidana) korporasi dalam tindak pidana korupsi yang sudah diatur oleh Undang-Undang tentang Pemberantasan Tindak Pidana korupsi masih memiliki kelemahan-kelemahan diantaranya: Pertama, masalah kapan korporasi melakukan tindak pidana korupsi, sudah diatur tetapi masih belum jelas mengenai pengertian hubungan kerja dan hubungan lainnya sehingga dapat menimbulkan kesimpangsiuran penafsiran yang dapat menjadi salah satu masalah pada saat aplikasi; Kedua, masalah tindak pidana korupsi yang dilakukan oleh korporasi, khususnya mengenai pemufakatan jahat; dan Ketiga, masalah sanksi pidana terhadap korporasi antara lain: masalah perumusan pemberatan sanksi pidana pada pasal 2 ayat (2), masalah kapan dikatakan terjadinya pengulangan tindak pidana korupsi, dan masalah perumusan sanksi pidana pokok terhadap korporasi dalam pasal 20 ayat (7). ${ }^{17}$

17 Orpa Ganefo Manuain, Pertanggungjawaban Pidana Korporasi dalam Tindak Pidana Korupsi, Tesis, (Semarang: Magister Hukum Universitas Diponegoro, 2005), hlm.110-11. 
Ketidakjelasan regulasi (Pasal 143 ayat 2 huruf a KUHAP) terkait mekanisme pembuktian korporasi di persidangan. Misalnya berkaitan dengan masalah penulisan identitas (salah satunya jenis kelamin) korporasi sebagai terdakwa. Dalam konteks ini Penuntut Umum akan kesulitan menulis surat dakwaan. Undang-undang tidak memberikan jalan keluar sama sekali. ${ }^{18}$ Dapat dikatakan telah terjadi kekosongan hukum acara, tentang tata cara penanganan tindak pidana korporasi. Akibatnya aparat penegak hukum masih ragu dan belum berani memeriksa korporasi sebagai tersangka/ terdakwa. Sehingga penanganan tindak pidana korporasi belum efektif. Penegakan hukum tindak pidana korporasi selama ini, hukum acaranya didasarkan pada pengetahuan dan pengalaman masing-masing aparat penegak hukum, kondisi ini menciptakan tidak adanya kesatuan hukum, sehingga menimbulkan perlakuan berbeda dalam penanganannya. ${ }^{19}$

Terdapat variasi bentuk pemidanaan korporasi akibat adanya multi tafsir dalam penerapan korporasi sebagai subjek hukum. Berdasarkan penelitian Penulis terdapat empat pola putusan pemidanaan terhadap korporasi di antaranya, yaitu: Pertama, korporasi dijadikan terdakwa dan dituntut di persidangan serta diputus pemidanaannya setelah pengurusnya terlebih dahulu diproses dan diputuskan pemidanaannya hingga berkekuatan hukum tetap (inkracht). Salah satu contohnya adalah perkara PT GJW yang didakwa telah melakukan tindak pidana korupsi dan dituntut ke persidangan oleh jaksa penuntut umum setelah terlebih dahulu direktur utamanya (SW) dipidana (berdasarkan Putusan Nomor 908/ Pid.B/2008/PN.Bjm tanggal 18 Desember 2008 yang mana putusan tersebut telah dikuatkan dengan Putusan Nomor 02/PID/SUS/2009/ PT.BJM tanggal 25 Februari 2009 dan kasasi terdakwa telah ditolak berdasarkan Putusan Nomor 936 K/Pid.Sus/2009 tanggal 25 Mei 2009). Majelis hakim melalui Putusan Nomor 812/Pid.Sus/2010/PN.Bjm memutuskan persis sama dengan tuntutan yaitu menyatakan PT GJW telah terbukti secara sah dan meyakinkan bersalah melakukan tindak pidana korupsi secara berlanjut sebagaimana dalam dakwaan primer, karenanya kepada PT GJW dijatuhkan pidana denda sebesar Rp1.300.000.000,- (satu miliar tiga ratus juta rupiah) serta pidana tambahan berupa penutupan sementara PT GJW selama enam bulan. Pada tingkat banding, Pengadilan Tinggi Banjarmasin melalui Putusan Nomor 04/PID.SUS/2011/PT.BJM menguatkan Putusan Nomor 812/Pid.Sus/2010/PN.Bjm tanggal 09 Juni 2011 dengan perbaikan sekedar mengenai besarnya sehingga menyatakan terdakwa PT GJW telah terbukti secara sah dan meyakinkan bersalah melakukan tindak pidana "korupsi secara berlanjut" dan karenanya menjatuhkan kepada terdakwa PT GJW pidana denda sebesar Rp1.317.782.129,-- (satu miliar tiga ratus tujuh belas juta tujuh ratus delapan puluh dua ribu seratus dua puluh sembilan rupiah) serta menjatuhkan pidana tambahan

18 Hifdzil Alim, Dkk. Pemidanaan Korporasi Atas Tindak Pidana Korupsi di Indonesia. (Yogyakarta, Pusat Kajian Antikorupsi Fakultas Hukum Universitas Gadjah Mada, 2013) hlm.68.

19 Surya Jaya, Corporate Criminal Liability: Implementasi Perma No.13 Tahun 2016, (Makalah disampaikan dalam Seminar Nasional Tentang Menjerat Korporasi Dengan Pertanggungjawaban Hukum yang diselenggarakan oleh Ikatan Hakim Indonesia pada tanggal 24 Maret 2017 di Hotel Mercure Ancol Jakarta). 
berupa penutupan sementara PT GJW selama enam bulan. ${ }^{20}$

Kedua, korporasi dijadikan terdakwa dan dituntut di persidangan serta diputus pemidanaannya tanpa (didahului dengan) pemidanaan terhadap pengurusnya. Salah satu contohnya adalah perkara PT Cakrawala Nusamedia (PT CN) didakwa melanggar Pasal 2 ayat (1) jo. Pasal 18 jo. Pasal 20 UndangUndang Pemberantasan Korupsi (primer) dan Pasal 3 jo. Pasal 18 jo. Pasal 20 Undang-Undang Pemberantasan Korupsi (subsider). YW selaku direktur PT CN mewakili di persidangan dan menyaksikan tuntutan terhadap korporasinya. Majelis hakim mengadili dengan Putusan Nomor 65/Pid.Sus/TPK/2016/PN.Bdg yang menyatakan terdakwa PT CN terbukti secara sah dan meyakinkan bersalah melakukan tindak pidana korupsi secara bersama-sama sebagaimana dalam dakwaan primer. Oleh karenanya menjatuhkan pidana kepada terdakwa PT CN dengan pidana denda sebesar Rp700.000.000,(tujuh ratus juta rupiah) dengan ketentuan jika terdakwa PT CN tidak membayar denda tersebut dalam tenggang waktu satu bulan terhitung sejak putusan tersebut berkekuatan hukum tetap, maka harta benda terpidana PT CN dapat disita oleh jaksa dan dilelang untuk membayar denda tersebut. ${ }^{21}$

Ketiga, putusan pemidanaan terhadap korporasi berdasarkan tuntutan jaksa penuntut umum tanpa dijadikan sebagai terdakwa. Salah satu contohnya adalah putusan pemidanaan terhadap PT Indosat Multi Media (IM2). Pada perkara ini yang ditetapkan dan diperiksa sebagai tersangka dan terdakwa di persidangan pengadilan tindak pidana korupsi adalah direktur utamanya yaitu IA. ${ }^{22}$ Jaksa penuntut umum menuntut agar pengadilan menyatakan terdakwa IA bersalah melakukan tindak pidana melakukan tindak pidana korupsi sebagaimana diatur dan diancam pidana dalam pasal perbuatan terdakwa tersebut sebagaimana dalam surat dakwaan primer dan menjatuhkan pidana terhadap terdakwa berupa pidana penjara selama sepuluh tahun, dikurangi selama terdakwa berada dalam tahanan, dan dengan membebankan terdakwa untuk membayar denda sebesar Rp500.000.000,(lima ratus juta rupiah), subsider enam bulan kurungan dan dengan perintah terdakwa segera ditahan di rutan serta uang pengganti sebesar Rp1.358.343.346.674,- (satu triliun tiga ratus lima puluh delapan miliar tiga ratus empat puluh tiga juta tiga ratus empat puluh enam ribu enam ratus tujuh puluh empat rupiah) dibebankan kepada PT Indosat dan PT $I M 2$, yang penuntutannya dilakukan secara terpisah. Majelis hakim melalui Putusan Nomor 01/Pid.Sus/2013/PN.Jkt.Pst memutuskan dan menyatakan terdakwa IA terbukti secara sah dan meyakinkan bersalah melakukan tindak pidana "korupsi dilakukan secara bersamasama", menjatuhkan pidana terhadap terdakwa tersebut dengan pidana penjara selama empat tahun dan menjatuhkan pidana denda sebesar Rp200.000.000,- (dua ratus juta rupiah) dan bila denda tersebut tidak dibayar diganti pidana

20 Budi Suhariyanto, Putusan Pemidanaan Terhadapn Korporasi Tanpa Didakwakan Dalam Perspektif Vicarious Liability, Jurnal Yudisial Volume Volume 10 Nomor 1 (April 2017), hlm.27-28.

21 Ibid, hlm.28.

22 IA didakwa melanggar Pasal 2 ayat (1) jo. Pasal 18 ayat (1) dan (3) Undang-Undang Pemberantasan Korupsi jo. Pasal 55 ayat (1) ke-1 KUH Pidana (primer) dan melanggar Pasal 3 jo. Pasal 18 ayat (1) dan (3) Undang-Undang Pemberantasan Korupsi jo. Pasal 55 ayat (1) ke-1 KUH Pidana. 
kurungan selama tiga bulan dan menghukum PT IM2 membayar uang pengganti sebesar Rp1.358.343.346.674,- (satu triliun tiga ratus lima puluh delapan miliar tiga ratus empat puluh tiga juta tiga ratus empat puluh enam ribu enam ratus tujuh puluh empat rupiah) paling lama dalam waktu satu tahun setelah putusan ini mempunyai kekuatan hukum tetap. Atas putusan ini, baik penuntut umum dan penasihat hukum terdakwa mengajukan banding. Melalui Putusan Nomor 33/PID/TPK/2013/PT.DKI menerima permintaan banding tersebut dan mengubah Putusan Nomor 01/Pid.Sus/2013/ PN.Jkt.Pst berkaitan dengan meniadakan putusan pidana pada PT IM2 yang sebelumnya dihukum membayar uang pengganti sebesar Rp1.358.343.346.674,- (satu triliun tiga ratus lima puluh delapan miliar tiga ratus empat puluh tiga juta tiga ratus empat puluh enam ribu enam ratus tujuh puluh empat rupiah) paling lama dalam waktu satu tahun setelah putusan ini mempunyai kekuatan hukum tetap. Sementara untuk putusan pemidanaan terhadap terdakwa IA adalah tetap dan sesuai dengan putusan pengadilan negeri. Pada tingkat kasasi, Mahkamah Agung memperbaiki amar Putusan Nomor 33/PID/TPK/2013/PT.DKI yang mengubah Putusan Nomor 01/Pid.Sus/ TPK/2013/PN.Jkt.Pst sekadar mengenai pidana denda dan uang pengganti sehingga amarnya menyatakan terdakwa IA terbukti secara sah dan meyakinkan bersalah melakukan tindak pidana "korupsi dilakukan secara bersama-sama" dan menjatuhkan pidana terhadap terdakwa tersebut dengan pidana penjara selama delapan tahun dan menjatuhkan pidana denda sebesar Rp300.000.000,- (tiga ratus juta rupiah) dan bila denda tersebut tidak dibayar diganti pidana kurungan selama enam bulan serta menghukum PT IM2 membayar uang pengganti sebesar Rp1.358.343.346.674,- (satu triliun tiga ratus lima puluh delapan miliar tiga ratus empat puluh tiga juta tiga ratus empat puluh enam ribu enam ratus tujuh puluh empat rupiah) dengan ketentuan apabila PT IM2 tidak membayar uang pengganti tersebut paling lambat satu bulan sesudah putusan mempunyai kekuatan hukum tetap, maka harta benda PT IM2 disita oleh jaksa dan dilelang untuk membayar uang pengganti tersebut. Atas putusan kasasi tersebut, terdakwa IA mengajukan peninjauan kembali. Mahkamah Agung pada tingkat peninjauan kembali memutuskan menolak permohonan peninjauan kembali dari pemohon peninjauan kembali/terpidana IA tersebut dan menetapkan putusan yang dimohonkan peninjauan kembali tersebut tetap berlaku. ${ }^{23}$

Keempat, putusan pemidanaan terhadap korporasi tanpa didakwakan dan dituntutkan oleh jaksa penuntut umum. Mahkamah Agung melalui Putusan Nomor 2239 K/PID.SUS/2012 mengesampingkan prosedur hukum (tanpa penetapan korporasi sebagai tersangka dan terdakwa) dengan menjatuhkan putusan pemidanaan terhadap korporasi tanpa didakwa dan dituntutkan oleh jaksa penuntut umum. Pada awalnya Jaksa penuntut umum mengajukan tuntutan agar majelis hakim memutuskan dengan menyatakan terdakwa Suwir Laut bersalah melakukan tindak pidana perpajakan yaitu dan menjatuhkan pidana terhadapnya berupa pidana penjara selama tiga tahun dikurangi selama terdakwa berada dalam tahanan sementara dengan perintah

23 Ibid, hlm.29-30. 
agar terdakwa segera ditahan, ditambah dengan denda sebesar Rp5.000.000.000,- (lima miliar rupiah) subsider enam bulan kurungan, menetapkan agar terdakwa membayar biaya perkara sebesar Rp5.000,- (lima ribu rupiah). Atas tuntutan ini, majelis hakim Pengadilan Negeri Jakarta Pusat dalam Putusannya Nomor 234/PID.B/2011/PN.JKT.PST memutuskan mengabulkan eksepsi prematur dari penasihat hukum terdakwa dan menyatakan surat dakwaan jaksa penuntut umum terhadap terdakwa karena prematur tidak dapat diterima. Berdasarkan putusan Pengadilan Negeri Jakarta Pusat tersebut, jaksa penuntut umum mengajukan upaya hukum banding. Pengadilan Tinggi Jakarta melalui Putusan Nomor 241/ PID/2012/PT.DKI menerima permintaan banding dari jaksa penuntut umum dan memutuskan menguatkan Putusan Nomor 234/PID.B/2011/ PN.JKT.PST yang dimohonkan banding tersebut. Tidak terima atas putusan Pengadilan Tinggi tersebut, jaksa penuntut umum mengajukan kasasi. Melalui Putusan Nomor 2239 K/PID. SUS/2012, Mahkamah Agung mengabulkan permohonan kasasi dari jaksa penuntut umum dan membatalkan Putusan Nomor 241/ PID/2012/PT.DKI tanggal 23 Juli 2012 yang menguatkan Putusan Nomor 234/PID.B/2011/ PN.JKT.PST. ${ }^{24}$

Berdasarkan realitas pemidanaan korporasi yang berbeda di atas maka pembaruan perundang-undangan terkait sistem pertanggungjawaban pidana korporasi sangat urgen, namun sehubungan dengan pembahasan dan pengesahan RUU KUHP akan memakan waktu lama maka institusi penegak hukum berinisiatif menerbitkan kebijakan terkait pemidanaan dan pertanggungjawaban pidana korporasi. Diantaranya dari Kejaksaan berupa penerbitan Surat Edaran Kejaksaan Agung RI Nomor B-036/A/Ft.1/06/2009 perihal Korporasi Sebagai Tersangka/Terdakwa Dalam Tindak Pidana Korupsi yang ditujukan kepada Kepala Kejaksaan Tinggi di seluruh Indonesia dan Peraturan Jaksa Agung Nomor: Per-028/A/ JA/10/2014 tentang Pedoman Penanganan Perkara Pidana Dengan Subjek Hukum Korporasi serta dari Mahkamah Agung berupa Peraturan Mahkamah Agung Nomor 13 Tahun 2016 tentang Tata Cara Penanganan Perkara Tindak Pidana Oleh Korporasi.

Penerbitan dan pemberlakuan Perma Nomor 13 Tahun 2016 ini dimaksudkan untuk mengisi kekosongan hukum khususnya hukum acara pidana dalam penanganan perkara pidana dengan pelaku Korporasi dan/atau Pengurus dan dapat dijadikan pedoman bagi penegak hukum dalam penanganan perkara pidana dengan pelaku Korporasi dan/atau Pengurus sehingga terwujudlah efektivitas dan optimalisasi penanganan perkara pidana dengan pelaku Korporasi dan/atau Pengurus. ${ }^{25}$ Untuk adanya kesatuan pemahaman tentang pengertian maka Perma mendefinisikan tindak pidana Korporasi yaitu tindak pidana yang dilakukan oleh orang berdasarkan hubungan kerja, atau berdasarkan hubungan lain, baik sendiri-sendiri maupun bersama-sama yang bertindak untuk dan atas nama Korporasi di dalam maupun di luar Lingkungan Korporasi. ${ }^{26}$

24 Ibid, hlm.21.

25 Pasal 2 Peraturan Mahkamah Agung Nomor 13 Tahun 2016 tentang Tata Cara Penanganan Perkara Tindak Pidana Oleh Korporasi.

26 Pasal 4 ayat (1) Peraturan Mahkamah Agung Nomor 13 Tahun 2016 tentang Tata Cara Penanganan Perkara Tindak Pidana Oleh Korporasi. 
Oleh karenanya Perma menentukan bahwa dalam menjatuhkan pidana terhadap korporasi, Hakim dapat menilai kesalahan korporasi antara lain: Pertama, korporasi dapat memperoleh keuntungan atau manfaat dari tindak pidana tersebut atau tindak pidana tersebut dilakukan untuk kepentingan korporasi; Kedua, korporasi membiarkan terjadinya tindak pidana; atau Ketiga, korporasi tidak melakukan langkahlangkah yang diperlukan untuk melakukan pencegahan, mencegah dampak yang lebih besar dan memastikan kepatuhan terhadap ketentuan hukum yang berlaku guna menghindari terjadinya tindak pidana. ${ }^{27}$

\section{Relevansi Pertanggungjawaban Pidana Korporasi Berdasarkan Corporate Culture Model dan Implikasinya Bagi Stabilitas Dunia Usaha}

Mencermati ketiga bentuk kesalahan korporasi yang ditentukan Perma Nomor 13 Tahun 2016 di atas, mengisyaratkan kehendak kuat dari Mahkamah Agung untuk memperbarui sistem pertanggungjawaban pidana korporasi yang selama ini dalam perundang-undnagan tidak diatur secara integral dan komprehensif. Sebagaimana diketahui bahwa ketepatan formulasi pertanggungjawaban pidana korporasi akan membawa implikasi yang luas dalam rangka penegakan hukumnya sebab kesalahan atau kelemahan dalam kebijakan formulasi ini merupakan kesalahan strategis yang dapat menghambat upaya pencegahan dan penanggulangan kejahatan korporasi pada tahap penerapannya. ${ }^{28}$

Mengingat pula bahwa isu utama yang menjadi kendala dalam penuntutan pertanggungjawaban pidana korporasi adalah masalah pembuktian kesalahannya. Hal tersebut memiliki peran penting pada saat persidangan sehingga menjadi jelas terkait sejauh mana penuntut umum harus membuktikan dan hal yang perlu diperhatikan hakim dalam menemukan kesalahan korporasi pada saat proses pembuktian sebagai dasar dari putusan. Dalam konteks ini Laode M. Syarief menyatakan bahwa bukan dari para hakim atau pengadilan yang menjadi penyebab pemidanaan korporasi dalam tindak pidana korupsi terkendala dan terhambat tetapi dari kalangan para Penyidiklah (khususnya Komisi Pemberantasan Korupsi) yang masih kurang yakin untuk menjadikan korporasi sebagai Terdakwa di persidangan tindak pidana korupsi. ${ }^{29}$

Sungguh disadari bahwa kesulitan untuk memenuhi unsur delik pidana yang dilanggar oleh korporasi tersebut disebabkan masih terpakunya aparat penegak hukum pada asas tiada pidana tanpa kesalahan yang memang dianut dalam ajaran pertanggungjawaban pidana dalam hukum pidana Indonesia. Kendala-kendala tersebut antara lain: Pertama, penentuan ada tidaknya tindak pidana oleh korporasi tidaklah dapat dilihat dengan sudut pandang biasa seperti pada tindak pidana umumnya, karena tindak pidana korporasi/

Pasal 4 ayat (2) Peraturan Mahkamah Agung Nomor 13 Tahun 2016 tentang Tata Cara Penanganan Perkara Tindak Pidana Oleh Korporasi.

28 Hasbullah F. Sjawie, Op Cit, hlm.323.

29 Laode M. Syarif, Tanggung Jawab Pidana Korporasi, Makalah disampaikan dalam Seminar tentang "Kedudukan dan Tanggung Jawab Korporasi Dalam Tindak Pidana Korupsi” yang diselenggarakan oleh Pusat Penelitian dan Pengembangan Hukum dan Peradilan Mahkamah Agung di Hotel Grand Mercure Jakarta Pusat tanggal 15 November 2016 
corporate crime seringkali merupakan bagian dari white collar crime. Kedua, penentuan subjek hukum yang dipertanggungjawabkan secara pidana berkaitan dengan kesalahan korporasi. Ketiga, penentuan kesalahan (schuld, mens rea) korporasi tidak mudah, karena terdapat hubungan yang begitu kompleks dalam tindak pidana terorganisasi (organizational crime) di antara dewan direksi (boards of directors), eksekutif dan manager pada satu sisi dan perusahaan induk (parent corporations), divisidivisi perusahaan (corporate divisions) dan cabang-cabang perusahaan (subsidairies) pada sisi lainnya. ${ }^{30}$

Tidak heran jika dalam delik korupsi sangat sulit membuktikan "kesalahan" suatu korporasi, baik berupa kesengajaan maupun kealpaan. Hal ini disebabkan karena subjek hukum dalam tindak pidana korupsitidak selaras dengan subjek hukum dalam KUHP. Sehingga Jaksa Penuntut Umum kesulitan mendapat teori-teori/doktrin dan dasar hukum tentang "kesalahan" orang perorang yang pada umumnya para ahli pidana sepakat bahwa hanya orang yang dapat memiliki unsur "kesalahan". Kekeliruan JPU dalam membuktikan perbuatan sebagai kesalahan individu (naturlijk persoon) dalam tindak pidana korporasi dapat mengakibatkan terdakwa diputus bebas (vrijspraak) oleh pengadilan. ${ }^{31}$ Selain itu terdapat kecenderungan adanya pencampuradukan berbagai pendekatan teori kesalahan korporasi pada praktek penegakan hukum sehingga berpotensi menambah beban penuntut umum dalam proses pembuktian. ${ }^{32}$
Pada dasarnya terdapat beberapa teori dan banyak diadopsi sebagai teori yang digunakan untuk menilai pertanggungjawaban pidana korporasi, diantaranya yaitu pertama, doktrin pertanggungjawaban pidana yang ketat menurut undang-undang (strict liability), jadi pertanggungjawaban korporasi semata-mata berdasarkan bunyi undang-undang dengan tanpa memandang siapa yang melakukan kesalahan. Kedua, doktrin pertanggungjawaban pengganti (vicarious liability), yang lebih menekankan pada pertanggungjawaban oleh pengurus korporasi sebagai"agen" perbuatan dari korporasi tersebut. Ketiga, teori identifikasi (direct corporate criminal liability) atau doktrin pertanggungjawaban pidana secara langsung yaitu perusahaan dapat melakukan sejumlah delik secara langsung melalui orang-orang yang berhubungan erat dengan perusahaan dan dipandang sebagai perusahaan itu sendiri. Keempat, teori agregasi yang menyatakan bahwa pertanggungjawaban pidana dapat dibebankan kepada badan hukum jika perbuatan tersebut dilakukan oleh sejumlah orang yang memenuhi unsur delik yang mana antara satu dengan yang lain saling terkait dan bukan berdiri sendirisendiri. Kelima, ajaran corporate culture model atau model budaya kerja yaitu ajaran yang memfokuskan pada kebijakan badan hukum yang tersurat dan tersirat mempengaruhi cara kerja badan hukum tersebut. Badan hukum dapat dipertanggungjawabkan secara pidana apabila tindakan seseorang memiliki dasar yang rasional bahwa badan hukum tersebut

30 Eddy O.S. Hiariej, Op Cit, hlm.161-162.

31 Eddy Rifa'i, Perspektif Pertanggungjawaban Pidana Korporasi sebagai Pelaku Tindak Pidana Korupsi, Mimbar Hukum Volume 26 Nomor 1 (Februari 2014), hlm.97.

32 Laksa Anindito, Lingkup Tindak Pidana Korupsi dan Pembuktian Kesalahan dalam Sistem Pertanggungjawaban Pidana Korporasi di Indonesia, Inggris dan Prancis, Jurnal Intergitas Volume 3 Nomor 1 (Maret 2017). Hlm.4 
memberikan wewenang atau mengizinkan perbuatan tersebut dilakukan. ${ }^{33}$

Pada asasnya Perma Nomor 13 Tahun 2016 menganut dan mengakomodasi beberapa teori pertanggungjawaban pidana korporasi di atas. Tidak ada aturan yang mendasari pemilahan atau kekhususan terhadapa suatu model pertanggungjawaban pidana hanya untuk suatu tindak pidana atau pengecualian terhadap tindak pidana yang lain. Dalam konteks ini Perma mengatur general (semua) tindak pidana, maka terhadap korupsi juga tidak luput dari penerapan beberapa pertanggungjawaban pidana korporasi tersebut. Termasuk penerapan corporate culture model yang mana meskipun korporasi tidak diuntungkan dari tindakan pengurusnya yang melakukan tindak pidana korupsi, maka korporasinya dapat dibebani pertanggungjawaban pidana bilamana budaya kerja yang ada dalam korporasi secara tidak langsung membiarkan atau tidak mampu mencegah terjadinya dampak dari tindak pidana tersebut.

Dapat dibandingkan di Australia yang mana telah mengeluarkan konsep "corporate culture", yang diwujudkan dalam Australian Criminal Code Act Tahun 1995. Peraturan ini telah mendefinisikan "corporate culture" sebagai prilaku, kebijakan, aturan, praktek atau pelatihan prilaku yang ada dalam tubuh perusahaan pada umumnya atau sebagai bagian dari tubuh perusahaan dimana pelanggaran terjadi. Pada Section 12.3 dari Australian Crminal Code mengatur bahwa salah satu cara pembuktian unsur kesalahan dalam suatu pelanggaran yang melibatkan suatu perusahaan dengan membuktikan bahwa budaya perusahaan (corporate culture) yang ada diperusahaan yang diarahkan, didukung, ditoleransi atau budaya perusahaan yang menyebabkan ketidakpatuhan dengan peraturan yang terkait atau bahwa perusahaan gagal menciptakan dan menjaga suatu budaya perusahaan yang mengharuskan kepatuhan dengan ketentuan terkait. ${ }^{34}$

Merujuk pula penerapan pertanggungjawaban pidana korporasi di Inggris, korporasi hanya dapat menghindari tanggungjawab apabila dapat membuktikan bahwa korporasi tersebut sudah melakukan upaya yang sesuai (adequate procedure) untuk dalam mencegah tindak pidana tersebut terjadi, yang dijamin sesuai dengan Section 7 (2) UK Bribery Act 2010 sebagai berikut: "But it is a defence for $C$ to prove that $C$ had in place adequate procedures designed to prevent persons associated with C from undertaking such conduct". Berdasarkan hal tersebut maka titik tekan pendekatan yang digunakan di Inggris adalah pemidanaan terhadap kegagalan korporasi dalam mencegah terjadinya tindak pidana (Failure of commercial organisations to prevent bribery). Walaupun demikian, menurut Katrin Decket pada prakteknya terdapat pendapat bahwa kesalahan dari organ dan representasi tetap harus dilihat dalam konteks "atas nama korporasi". ${ }^{35}$ Tidak seluruh kesalahan dari organ atau representasi dari korporasi dapat secara langsung diatribusikan menjadi kesalahan

Eddy O.S. Hiariej, Prinsip-Prinsip Hukum Pidana. (Yogyakarta: Cahaya Atma Pustaka, 2014), hlm.165-166.

34 Reda Manthovani, Penuntutan Korporasi sebagai Pelaku Tindak Pidana dalam Kejahatan di Sektor Kehutanan: Optimalisasi Penggunaan Undang-Undang Pencucian Uang dalam Pembuktian Tindak Pidana di Sektor Kehutanan di Indonesia yang dialkukan oleh Korproasi, Makalah dalam https://media.neliti.com, hlm.8. (diakses 1 September 2017)

35 Laksa Anindito, Op Cit, hlm. 15 
korporasi. Untuk menafsirkan "atas nama korporasi" tersebut. Korporasi tidak dapat dipertanggungjawabkan tanpa dilihat dalam rangka apa perbuatan tersebut dilakukan. ${ }^{36}$

Dasar pertanggungjawaban pengurus bagi korporasinya adalah adanya suatu kewajiban atau tugas yang melekat pada fungsi dan jabatan serta relasi hukum antara korporasi dan pengurusnya. Kewajiban dan relasi hukum tersebut dikenal dengan istilah fiduciary duty, yaitu antara lain berupa: (a). duty of care and diligence; (b). duty of skill; (c). obligation to be attentive; (d). Bussines judgement rule yaitu director's action should be the product of Reasonable investigation and consideration, serta diractor's decisions chould embody a rational basis for action. ${ }^{37}$ Pentingnya fiduciary duties ini adalah untuk memastikan sampai dimana suatu organ bertindak dalam batas wewenangnya sehingga ia tidak perlu bertanggungajawab secara pribadi. Di dalam praktik tidak mudah untuk membuktikan fiduciary duties ini terlaksana dengan benar atau tidak, karena atau kualitas masingmasing ditentukan sendiri oleh korproasi yang bersangkutan, yang mungkin berbeda-beda. Hakimlah yang akan memutuskan apakah telah terjadi pelanggaran atas fiduciary duties atau tidak. Karena itu diperlukan kriteria lain untuk menjadi dasar pertanggungjawaban pengurus korproasi terhadap suatu tindakan, yaitu dengan menggunakan criteria Slavenburg, melalui sejumlah pertanyaan yaitu Pertama, pengurus organisasi/korporasi merupakan fungsionaris yang dapat menghentikan atau mencegah perilaku pidana (kedudukannya de facto maupun de jure memiliki power/powerfull) dan Kedua, pengurus tersebut memahami bahwa terdapat kemungkinan yang cukup bahwa pelanggaran sangat mungkin terjadi. ${ }^{38}$ Selain itu kriteria Slavenburg juga mengenal duty of care. Tidak memenuhi duty of care ini dapat menyebabkan seseorang dianggap sebagai pelaku tindak pidana. Dalam hukum lingkungan duty of care ini dapat berbentuk peringatan akan bahaya yang sudah diberikan, tetapi gagal mengatasi bahaya yang ditimbulkan.

Seharusnya korporasi tidak dapat dikenakan pertanggungjawaban pidana apabila directing mind and will korporasi melakukan tindak pidana terhadap korporasi mereka sendiri dan korporasi yang bersangkutan juga mengalami kerugian atas tindakan directing mind and will-nya. Parameter ini sekaligus menunjukkan bahwa penyebutan tindak pidana yang dilakukan korporasi adalah apabila tindakan tersebut memberikan manfaat dan/atau keuntungan bagi korporasi. ${ }^{39}$ Untuk penentuan kesalahan yang tidak berkaitan secara fungsional dengan kegunaan atau kemanfaatan yang didapat secara langsung oleh korporasi, nampaknya kurang relevan digunakan untuk perkara tindak pidana korupsi yang notabene mensyaratkan adanya unsur memperkaya suatu korporasi. Apalagi mengingat pembuktian atas unsur memperkaya korporasi dalam konteks perkara

Ibid, hlm.19.

37 Sudung Situmorang, Pertanggungjawaban Korporasi dalam Sistem Hukum Pidana Indonesia, Tesis. (Jakarta: Fakultas Hukum Universitas Indonesia, 2003). hlm.65-66

38 Ibid, hlm.66.

39 Lu Sudirman dan Feronica, Pembuktian Pertanggungjawaban Pidana Lingkungan dan Korupsi Korporasi di Indonesia dan singapura, dalam Mimbar Hukum Volume 23 Nomor 2 (Juli 2011), hlm. 302 
tindak pidana korupsi yang dilakukan korporasi dan layak dibebankan pertanggungjawabannya pada korporasi adalah sangat penting.

Pada konteks perkara tindak pidana korupsi, patut dipertanyakan relevansi diterapkan pertanggungawaban berdasarkan corporate culture model bilamana korporasi dibebankan suatu kesalahan yang dilakukan pengurusnya dalam hal melakukan tindak pidana korupsi dan tidak ada kaitannya sama sekali dengan maksud dan tujuan untuk memperkaya atau memberikan keuntungan kepada korporasi, maka akan "berlebihan" jika korporasinya turut dipidana atas sebuah kesalahan (hanya) karena tidak melakukan pencegahan. Pada suatu tindak pidana korupsi yang dilakukan oleh seorang pengurus korporasi yang peruntukannya adalah untuk pribadi (bukan dalam rangka menguntungkan korporasi), maka kurang tepat jika korporasi juga harus dibebani pertanggungjawaban pidana disebabkan tidak mengkondisikan budaya kerja yang kondusif atas perilaku koruptif pengurusnya. Malahan sesungguhnya korporasi mengalami kerugian (selain kerugian negara) dan menjadi korban dari tindak pidana korupsi yang dilakukan oleh Pengurusnya tersebut.

Mengingat pula bahwa jika corporate culture model dalam perkara tindak pidana korporasi yang tak melakukan pencegahan sehingga turut dijadikan pelaku tindak pidana korupsi, maka sesaat proses peradilan dengan dimulainya penyidikan dan diketahui oleh publik maka saat itu juga meskipun korporasi itu belum tentu diputuskan bersalah dan dipidana, korporasi akan mendapatkan sanksi reputasi berupa kepercayaan investor yang akan menarik sahamnya sehingga berpengaruh pada pengelolaan serta stabilitas perekonomian perusahaan yang berimplikasi juga kepada hajat hidup dari buruh korporasi tersebut. Dalam konteks ini tanggungjawab fungsional dibebankan pula kepada Pemerintah/negara selain tanggungjawab kepada Pelaku tindak pidana korporasi. Bentuk tanggungjawabnya sesuai dengan analisis/kajian dari pemahaman masalah korban, penimbul korban, serta akibat-akibat yang menimbulkan masalah korban sebagai kenyataan ${ }^{40}$ dan kesejahteraan masyarakat.

Persoalan mendasar terkait eksistensinya dengan hajat hidup buruh dan kelangsungan ekonomi masyarakat serta akibat lain berupa krisis di bidang lain senyatanya harus menjadi pertimbangan dalam pemidanaan korporasi berdasarkan alasan corporate culture model. Dalam konteks ini Suzuki mengingatkan Agar dalam menjatuhkan pidana pada korporasi, misalnya dalam bentuk penutupan seluruh atau sebagian usaha, dilakukan secara hatihati. Hal ini disebabkan karena dampak putusan tersebut sangat luas. Yang akan menderita tidak hanya yang berbuat salah, tetapi juga orang-orang yang tidak berdosa seperti buruh. Untuk mencegah dampak negatif pemidanaan korporasi, hendaknya dipikirkan untuk mengasuransikan para buruh/pekerja dan pemegang saham. Sehingga efek pemidanaan terhadap korporasi yang mempunyai dampak negatif dapat dihindarkan. ${ }^{41}$

40 Etty Utju R. Koesoemahatmadja, Hukum Korporasi : Penegakan Hukum terhadap Pelaku Economic Crimes dan Perlindungan Abuse of Power. (Bogor: Ghalia Indonesia.2011), hlm.125.

41 Suzuki, Yoshio. The Role of Criminal Law in the Control of Social and Economic Offences. Hlm.202. dalam Muladi dan Dwidja Priyatno,Pertanggungjawaban Pidana Korporasi. (Jakarta: Kencana, 2010), hlm.143. 
Menimbang bahwa Perma Nomor 13 Tahun 2016 tidak memberikan perlindungan terhadap pemegang saham atas perusahaan publik yang dibebankan pertanggungjawaban pidana atas tindak pidana korupsi yang dilakukan oleh Pengurusnya yang notabene dapat mencakup tindakan karyawan (non direksi) dan pihak lain yang tidak dalam hubungan kerja ini menimbulkan risiko besar bagi korporasi bila pemeriksaan dilakukan dengan tidak cermat atau tergesa-gesa (tanpa due process of law). Maka untuk itu diperlukan Aparat Peradilan termasuk Hakim yang memiliki kompetensi profesional tinggi dan integritas baik sehingga dapat mengejawantahkan due process of law sehingga tidak terjadi "kriminalisasi terhadap korporasi" yang berdampak buruk terhadap kelangsungan usaha dan nasib karyawan dan stakeholders lainnya ${ }^{42}$ yaitu kesejahteraan masyarakat.

\section{Penutup}

Perma Nomor 13 Tahun 2016 yang diterbitkan dan diberlakukan dalam rangka meningkatkan efektivitas penanggulangan tindak pidana korporasi perlu diterapkan secara hati-hati. Khususnya terkait dengan penerapan corporate culture model dalam perkara tindak pidana korupsi yang dilakukan oleh pengurus korporasi tetapi korporasinya juga dapat dituntutkan pertanggungjawaban pidana. Apalagi perbuatan korupsi pengurusnya tersebut tidak ada kaitannya sama sekali dengan maksud dan tujuan untuk memperkaya atau memberikan keuntungan kepada korporasi, maka akan "berlebihan" jika korporasinya turut dipidana atas sebuah kesalahan (hanya) karena tidak melakukan pencegahan. Sesungguhnya korporasi mengalami kerugian (selain kerugian negara) dan menjadi korban dari tindak pidana korupsi yang dilakukan oleh Pengurusnya tersebut. Semisal saat proses peradilan dengan dimulainya penyidikan dan diketahui oleh publik maka saat itu juga meskipun korporasi itu belum tentu diputuskan bersalah dan dipidana, korporasi akan mendapatkan sanksi reputasi berupa kepercayaan investor yang akan menarik sahamnya sehingga berpengaruh pada pengelolaan serta stabilitas perekonomian perusahaan yang berimplikasi juga kepada hajat hidup dari buruh korporasi tersebut. Mengingat Perma Nomor 13 Tahun 2016 tidak memberikan perlindungan terhadap pemegang saham atas perusahaan publik yang dibebankan pertanggungjawaban pidana atas tindak pidana korupsi yang dilakukan oleh Pengurusnya yang notabene dapat mencakup tindakan karyawan (non direksi) dan pihak lain yang tidak dalam hubungan kerja ini menimbulkan risiko besar bagi korporasi bila pemeriksaan dilakukan dengan tidak cermat atau tergesa-gesa (tanpa due process of law).

\section{Daftar Pustaka}

\section{Buku}

Ali, Mahrus. Kejahatan Korporasi, (Yogyakarta: Arti Bumi Intaran, 2008).

Alim, Hifdzil Dkk. Pemidanaan Korporasi Atas Tindak Pidana Korupsi di Indonesia. (Yogyakarta, Pusat Kajian Antikorupsi Fakultas Hukum Universitas Gadjah Mada, 2013)

Hiariej, Eddy O.S. Prinsip-Prinsip Hukum Pidana, (Yogyakarta: Cahaya Atma Pustaka, 2014)

Irianto, Sulistyowati dan Shidarta. Metode Penelitian Hukum (Konstelasi dan Refleksi) (Jakarta: Yayasan Pustaka Obor Indonesia. 2011)

42 Hariyadi B. Sukamdani, Op Cit, hlm.8 
Koesoemahatmadja, Etty Utju R. Hukum Korporasi : Penegakan Hukum terhadap Pelaku Economic Crimes dan Perlindungan Abuse of Power. (Bogor: Ghalia Indonesia.2011)

Kristian, Hukum Pidana Korporasi: Kebijakan Integral (Integral Policy) Formulasi Pertanggungjawaban Pidana Korporasi di Indonesia, (Bandung: Nuansa Aulia, 2014)

Manuain, Orpa Ganefo. Pertanggungjawaban Pidana Korporasi dalam Tindak Pidana Korupsi, Tesis, (Semarang: Magister Hukum Universitas Diponegoro, 2005)

Marzuki, Peter Mahmud. Penelitian Hukum (Jakarta: Kencana, 2014)

Muladi dan Dwidja Priyatno,Pertanggungjawaban Pidana Korporasi. (Jakarta: Kencana, 2010)

Sjawie, Hasbullah F. Direksi Perseroan Terbatas serta Pertanggungjawaban Pidana Korporasi, (Bandung: Citra Aditya Bhakti, 2013)

Sudung Situmorang, Pertanggungjawaban Korporasi dalam Sistem Hukum Pidana Indonesia, Tesis. (Jakarta: Fakultas Hukum Universitas Indonesia, 2003)

Susanto, I. S. Kejahatan Korporasi, (Semarang: BP Universitas Diponegoro, 1995).

\section{Makalah/Artikel/Prosiding/Hasil Penelitian}

Anindito, Laksa. Lingkup Tindak Pidana Korupsi dan Pembuktian Kesalahan dalam Sistem Pertanggungjawaban Pidana KOrporasi di Indonesia, Inggris dan Prancis, Jurnal Intergitas Volume 3 Nomor 1 (Maret 2017)

Rifa'i, Eddy. Perspektif Pertanggungjawaban Pidana Korporasi sebagai Pelaku Tindak Pidana Korupsi, Mimbar Hukum Volume 26 Nomor 1 (Februari 2014).

Sudirman, Lu dan Feronica, Pembuktian Pertanggungjawaban Pidana Lingkungan dan Korupsi Korporasi di Indonesia dan singapura, dalam Mimbar Hukum Volume 23 Nomor 2 (Juli 2011)
Suhariyanto, Budi. Progresivitas Putusan Pemidanaan Terhadap Korporasi Pelaku Tindak Pidana Korupsi, Jurnal De Jure Volume 16 Nomor 2 (Juni 2016).

Suhariyanto, Budi. Putusan Pemidanaan Terhadap Korporasi Tanpa Didakwakan Dalam Perspektif Vicarious Liability, Jurnal Yudisial Volume Volume 10 Nomor 1 April 2017

Syarif, Laode M. Tanggung Jawab Pidana Korporasi, Makalah disampaikan dalam Seminar tentang "Kedudukan dan Tanggung Jawab Korporasi Dalam Tindak Pidana Korupsi" yang diselenggarakan oleh Pusat Penelitian dan Pengembangan Hukum dan Peradilan Mahkamah Agung di Hotel Grand Mercure Jakarta Pusat tanggal 15 November 2016

Sukamdani, Hariyadi B. Korporasi sebagai Subyek Hukum Pidana Pasca Perma No.13 Tahun 2016: Pandangan Dunia Usaha, Makalah seminar dalam Rangka HUT IKAHI ke-64 tahun di Hotel Mercure Ancol Jakarta pada hari Selasa 21 (Maret 2017).

Surya Jaya, Corporate Criminal Liability: Implementasi Perma No.13 Tahun 2016, (Makalah disampaikan dalam Seminar Nasional Tentang Menjerat Korporasi Dengan Pertanggungjawaban Hukum yang diselenggarakan oleh Ikatan Hakim Indonesia pada tanggal 24 Maret $2017 \mathrm{di}$ Hotel Mercure Ancol Jakarta.

\section{Internet}

Manthovani, Reda. Penuntutan Korporasi sebagai Pelaku Tindak Pidana dalam Kejahatan di Sektor Kehutanan: Optimalisasi Penggunaan UndangUndang Pencucian Uang dalam Pembuktian Tindak Pidana di Sektor Kehutanan di Indonesia yang dilakukan oleh Korporasi, Makalah dalam https:// media.neliti.com, (diakses 1 September 2017) 